Sharif University of Technology
Scientia Iranica
SCIENTIA
I RAN ICA
http://scientiairanica.sharif.edu

\title{
Numerical evaluation of geocell-reinforced flexible pavements under traffic loads
}

\author{
M.R. Arvin ${ }^{a, *}$, E. Rezaei ${ }^{a}$, and M. Bahmani Shoorijeh ${ }^{b}$ \\ a. Department of Civil Engineering, Fasa University, Fasa, P.O. Box 7461686131, Iran. \\ b. Department of Civil and Environmental Engineering, Shiraz University, Shiraz, Iran. \\ Received 19 September 2015; received in revised form 16 July 2016; accepted 16 January 2017
}

\section{KEYWORDS \\ Pavement; \\ Shakedown; \\ Geocell; \\ Reinforcement; \\ Reoated loads; \\ Finite element.}

\begin{abstract}
Although several analytical and numerical approaches have been devoted to investigate the shakedown behavior of pavements, shakedown limit of reinforced pavements, in particular geocell-reinforced pavements, has not been explored yet by load-displacement numerical means. In this study, behavior of a typical three-layer pavement reinforced with geocell was investigated under repeated vertical traffic loads by three-dimensional finite element elasto-plastic analysis based on shakedown failure and serviceability criteria. Three different cases of unreinforced, base-layer-reinforced, and subgrade-reinforced pavements were taken into consideration and subjected to a variety of vehicle loads. Shakedown limit, which is the multiplication of initial load by shakedown coefficient for each pavement under each load, was determined through a trial and error process. Results indicated that reinforcement of subgarde by geocell significantly improved the shakedown coefficients of pavements. Reinforcement of base by geocell increased the shakedown coefficient of pavements as well as but not as much as subgrade reinforcement. Results also indicated the sensitivity of shakedown coefficient and shakedown bearing capacity to intensity and shape of the contact area of different loads in a way that the most extreme case was observed for $P=22$ ton. Variation of accumulated plastic displacement prior to shakedown state has also been presented and discussed.

(C) 2018 Sharif University of Technology. All rights reserved.
\end{abstract}

\section{Introduction}

Roads, as the structures that are subjected to traffic loads, are designed in a way that preserve their serviceability in an acceptable range during their lifetime. When the pavements under repeated loads of traffic cease to further develop plastic displacement and strains and starts begin to behave elastically, it can be claimed that they have reached a safe state at the

\footnotetext{
*. Corresponding author. Tel.: +987153344738 E-mail addresses: m.r.arvin@fasau.ac.ir (M.R. Arvin); ehsanrezaiefa@gmail.com (E. Rezaei); bahmani.mostafa@gmail.com (M.Bahmani Shoorijeh)
}

time and even times beyond that. This phenomenon is called shakedown, which is on the opposite side of inadaptation, in which high intensity of applied repeated loads leads to increasing accumulated strains and displacement and final collapse of the structure due to ratcheting or alternating plasticity. Depending on the intensity of the applied repeated loads, all three kinds of behavior, namely, purely elastic, shakedown, and inadaptation, may occur in structures.

Observations of the laboratory and full-scale tests on the pavements under cyclic or traffic loads suggest the possibility of the occurrence of shakedown. Jupsi carried out full-scale tests on pavements and realized that, depending on the domain of the applied repeated loads, pavements underwent either inadaptation due to gradual or sharp increase in permanent settlement, 
or experienced shakedown [1]. Similar results were obtained by Ravindra [2] and Ravindra and Small [3], who performed tests on recycled-crushed-concrete base and sandy subgrade.

By definition, a domain can be imagined for an specified structure in the load space under which the structure experiences shakedown state and beyond that fails due to inadaptation. The aforementioned domain is linked to the existing load domain via the so-called shakedown coefficient. Shakedown coefficient can be determined by means of experimental, analytical, and numerical methods. Preliminary lower bound and upper bound shakedown theories that were introduced by Melan [4] and Koiter [5], respectively, were theoretically and numerically developed for use in a range of scientific areas. Sharp and Booker [6] were the first to apply these theories to find the shakedown coefficient of pavements. Afterwards, upper and lower bound theorems of shakedown were progressively applied in pavements, especially for two-dimensional analysis of pavements [7-14]. Three-dimensional analysis of pavements based on shakedown limit theories are restricted to a few research works [15], due to its complexity and requirement of a large computer memory to handle optimization of the results. Furthermore, shakedown limit of reinforced pavements has not been investigated by limit shakedown theorem until now, as far as the authors know. The most important advantages of shakedown limit theorems are their simplicity to apply and their ability to find shakedown coefficient directly; nevertheless, they fail to take the accumulated plastic strains and displacements prior to shakedown limit into account. It is obvious that structures might fail to perform correctly due to unacceptable permanent accumulated displacement, even though they are under shakedown limit. It is possible to determine shakedown limit of structures by elasto-plastic analysis provided that loads and their variations are specified. In contrast to classical shakedown theorems, this method is able to determine the accumulated plastic displacements prior to shakedown limit. However, analysis of structures under repeated loads is time consuming and assessment of the optimum shakedown coefficient requires numerous trials and errors.

Investigations show that using geosynthetics for reinforcement increases the strength and decreases the settlement of pavements, consequently improving their operating functions. Geosynthetics are synthetic materials that are generally polymeric. Geosynthetics are a family of eight members including geocell, which is different from the other members due to its threedimensional honeycomb structure. Geocell was first used by US army corps of engineering for enhancing vehicular mobility of roads on loose sandy subgrades [16]. Elasticity modulus of geocell-reinforced granular soils increases with respect to unreinforced granular soils because of higher confining pressure developed due to geocell and stress dependency of granular soils. The stiffened soil distributes the loads over a wider area and, consequently, results in lower settlement of the underlying layer [17]. Triaxial tests carried out on granular soil samples reinforced by single cell of geocell [18] and two, three, and four cells of geocell [19] suggest that geocell strengthens the granular soil by developing apparent cohesion $(\mathrm{Cr})$ and making a negligible change in internal friction angle. Various researches, mostly experimental, have been done to investigate the geocell-reinforced structures under monotonic and cyclic loads. Latha et al. evaluated the influences of reinforced pavements with different geosynthetics, including geocell, on the reduction in rutting depth through a series of field tests and observed that geocell had the best performance compared to the other types of geosynthetics [20].

Monotonically loaded foundations resting on geocell-reinforced soil have also been investigated through several numerical researches by elasto-plastic analysis via different numerical approaches including finite element method [21,22] and finite difference method [23,24]. Taking advantage of advanced elastoplastic constitutive laws enables us to incorporate shakedown phenomenon, which is another way to analyze the pavements under repeated loads. Chazalon model for unbounded gravel is among the limited works on developing such models for unreinforced pavements [25]. However, as far as the authors know, no analogous model able to incorporate shakedown and inadaptation phenomenon for soil-geocell composite has been developed so far. In the absence of such models, another alternative would be using models like Drucker-Prager or Mohr-Coulomb to analyze the structures under successive loadings and unloadings. In this regard, Yan et al. presented a three-dimensional mechanistic-empirical model for unpaved roads [26].

Only a few researches are available on numerical analysis of geocell-reinforced structures under cyclic loads. Leshchinsky and Ling investigated the influences of reinforcement of ballast layer by geocell on the performance of railroads, using finite element analysis [27]. However, they considered repeated loads of train as monotonic loads. Their parametric studies showed that increase in strength of infill materials and geocell stiffness had considerable effects on the reduction in lateral displacement of ballast and induced stresses in subgrade. Leshchinsly and Ling carried out experimental and numerical evaluations of unreinforced and geocell-reinforced (in one and two layers) axisymmetric gravelly embankments under monotonic and cyclic loads [28]. In this research work, axial stiffness increased under monotonic loads and shakedown behavior under cyclic loads was observed through test and captured in FE analysis as well. 
Although experimental researches on geocellreinforced soils mostly show that shakedown may happen under some conditions, none of them concentrate on determination of shakedown limit. The same is true for numerical research works on soils that are reinforced by geocell.

In the present study, shakedown limit of a typical three-layer flexible pavement resting on a weak subgrade is investigated in three situations, namely, unreinforced, geocell-reinforced base layer, and reinforced subgrade. Both failure and serviceability criteria are taken into consideration in determination of shakedown limit. Effects of geocell reinforcement and different types of load on shakedown limits are also studied.

\section{Solution procedure}

In order to determine the shakedown coefficient, which is a multiplier of the initial applied load, different types of vehicle loads are considered as initial loads and applied cyclically to pavements after being multiplied by different load multipliers. To do so, first, the pavement, either unreinforced or reinforced, is modeled in a finite element software, here ABAQUS, and traffic loads are applied, as much as possible, analogous to practical loads in terms of shape and intensity. Then, elasto-plastic analysis is employed to find stress, strain, and displacement fields of the pavements. If failure and serviceability criteria are fulfilled simultaneously for a specified load according to shakedown definition, it can be claimed that the factored load is a shakedown load, but not necessarily the best or optimum shakedown load. To find the best shakedown limit, a trial and error procedure is required.

As mentioned earlier, two types of criteria, namely, failure and serviceability, must be fulfilled to ensure that the applied load is a shakedown load. Shakedown failure criterion is simply elastic behavior of structure following some primary plastic strain accumulation. Accordingly, three different serviceability criteria are considered herein. Firstly, maximum settlement of surface layer is limited to an allowable value; secondly, loads must not induce fatigue cracks; and, thirdly, excessive rutting must be prohibited. In this study, the aforementioned criteria are defined as follows:

1. Failure criterion: Pavement reaches shakedown state if plastic displacement caused by the $i$ th cycle of load is equal to or less than $0.4 \%$ of the plastic displacement induced by the first load cycle. In addition, plastic displacement rate must follow a decreasing trend;

2. First serviceability criterion: Maximum settlement of the pavement surface must not exceed $1 \mathrm{~cm}$;

3. Second serviceability criterion: Tensile strain be- neath asphalt layer must not exceed allowable limit to prevent fatigue cracks. Asphalt institute formula that predicts the number of load cycles leading to fatigue cracks $\left(N_{f}\right)$ with respect to elastic modulus $(E)$ and horizontal tensile strain beneath the asphalt layer in the direction of tyre movement $\left(\varepsilon_{t}\right)$ is as follows [29]:

$$
N_{f}=0.0796\left(\varepsilon_{t}\right)^{-3.291}(E)^{-0.854}
$$

where $E$ is in PSI unit. Having $E$ value and introducing the number of load cycles determined from analysis into Eq. (1), critical tensile strain will be obtained. Certainly, if the tensile strength determined by the analysis is smaller than the corresponding critical value, the second serviceability criterion is satisfied;

4. Third serviceability criterion: Vertical compressive strain on top of subgrade layer must not exceed the allowable limit to prevent unacceptable rutting. In Shell and Asphalt Institute design methods [29], the relation between number of load cycles that are enough to induce rutting failure $\left(N_{d}\right)$ and vertical compressive strain on top of subgrade layer is introduced by the following formula:

$$
N_{d}=f_{4}\left(\varepsilon_{c}\right)^{-f_{s}}
$$

In Eq. (2), $f_{4}$ and $f_{5}$ are experimental factors, which are taken equal to $6.15 \times 10^{-7}$ and 4 , respectively, according to Shell method with $50 \%$ reliability. Introducing the number of load cycles in shakedown state assessed by the analyses into Eq. (2), critical vertical compressive strain is obtained. The third serviceability criterion is met if the analytical vertical compressive strain on top of the subgrade course is smaller than its critical counterpart.

The next step is to find the best shakedown coefficient, which is actually the maximum possible shakedown factor that puts the pavement on the verge of inadaptation. To do so, a trial and error procedure is followed in which different load factors are tried and fulfillment of all the above mentioned four criteria is evaluated. That is, load factors are increased until one or more of the shakedown criteria are violated and then decreased slightly so that all requirements are met. This way the best or maximum shakedown load factor is obtained.

\section{Problem definition}

\subsection{Geometry and material properties of pavements layers}

The geometry of the pavements considered in this study was selected according to the Iranian code for road geometry and had $3.65 \mathrm{~m}$ and $1.85 \mathrm{~m}$ widths of 
Table 1. Properties of pavement layers.

\begin{tabular}{lccccccc}
\hline \multicolumn{1}{c}{ Layer } & Material & $\begin{array}{c}\boldsymbol{\gamma} \\
\left(\mathbf{k N} / \mathbf{m}^{\mathbf{3}}\right)\end{array}$ & $\boldsymbol{\nu}$ & $\begin{array}{c}\boldsymbol{c} \\
\left(\mathbf{k N} / \mathbf{m}^{\mathbf{2}}\right)\end{array}$ & $\boldsymbol{\phi}^{\circ}$ & $\begin{array}{c}\boldsymbol{E} \\
\left(\mathbf{k N} / \mathbf{m}^{\mathbf{2}}\right)\end{array}$ & $\begin{array}{c}\text { Thickness } \\
(\mathbf{c m})\end{array}$ \\
\hline Surface & Asphalt & 22 & 0.35 & 250 & 38 & 3855750 & 10 \\
Base & $\mathrm{GW}$ & 20 & 0.35 & 5 & 35 & 300000 & 20 \\
Subbase & $\mathrm{SW}$ & 19.5 & 0.35 & 5 & 37 & 200000 & 30 \\
Subgrade & $\mathrm{CL}$ & 17 & 0.4 & 4 & 30 & 3000 & - \\
\hline
\end{tabular}

Table 2. Properties of geocell [27].

\begin{tabular}{ccccc}
\hline Material & $\begin{array}{c}\text { Height } \\
(\mathbf{c m})\end{array}$ & $\boldsymbol{\nu}$ & $\begin{array}{c}\boldsymbol{\gamma} \\
\left(\mathbf{k N} / \mathbf{m}^{\mathbf{3}}\right)\end{array}$ & $\begin{array}{c}\boldsymbol{E} \\
(\mathbf{k P a})\end{array}$ \\
\hline Geocell & 20 & 0.35 & 20 & $2.07 \mathrm{E}+09$ \\
\hline
\end{tabular}

driveway and shoulder, respectively. Besides, slope of the road embankment was considered 1:2 based on the AASHTO guide for design of pavements [30]. Well graded sand (SW) and well graded gravel (GW) soil types were considered for base and subbase layers, respectively [30]. The surface course was assumed to be bituminous asphalt. In order to have a better insight into the effect of soil reinforcement on the behavior of pavements, a weak material, namely, light plasticity clay (CL), was assigned to subgrade layer. Materials were considered to behave in elastic-perfectly plastic manner and obey Mohr-Coulomb failure criterion. Thicknesses of asphalt, base, and subbase layers were taken $10 \mathrm{~cm}, 20 \mathrm{~cm}$, and $30 \mathrm{~cm}$, respectively. Subgrade was assumed as a layer of $2 \mathrm{~m}$ thickness resting on the bedrock. Thicknesses, elastic properties, and strength parameters for each pavement layer can be seen in Table 1.

Furthermore, dilation angle of all materials, except for the surface layer, was assumed to be nearly zero, which was a conservative assumption. The dilation angle of asphalt layer was taken as $5^{\circ}$. Assuming excellent drainage condition for dry regions, pavements with properties such as those in Table 1 had Structural Number (SN) equal to 7 according to AASHTO design code [30]. Geocells were considered to behave in a purely elastic manner and were modeled as $40 \times 40 \mathrm{~cm}$ square cells with $20 \mathrm{~cm}$ height as shown in Figure 1. Elastic properties of geocell material were taken same as those considered by Lechchinsky and Ling [27] and have been represented in Table 2 .

\subsection{Loads}

In order to define the vehicle loads on pavements, load intensity and pavement-tire contact area must be determined in advance. Pavement-tire contact area is a function of contact pressure, which is dependent on tire pressure itself. Contact pressure can be equated with tire pressure with a quite acceptable error, especially for high tire pressures [31]. Shape of pavement-tire

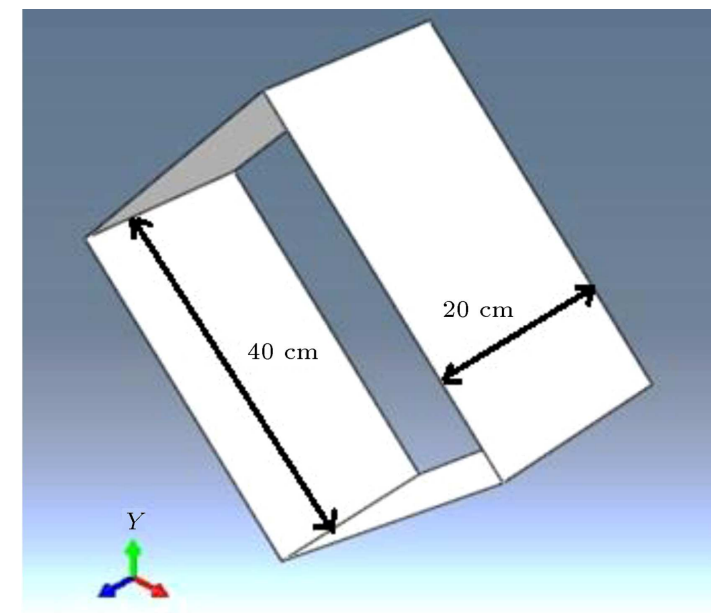

Figure 1. Geometry of a single cell.

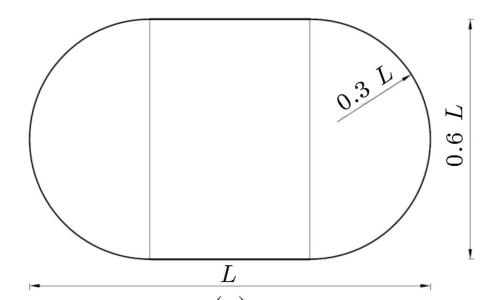

(a)

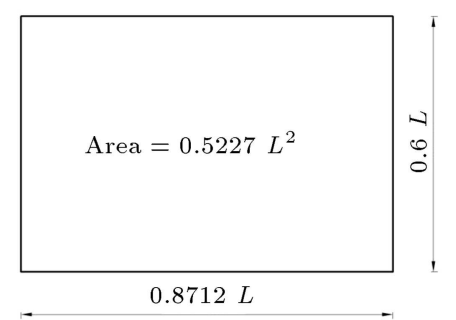

(b)

Figure 2. Tire-surface contact area: (a) Actual area and (b) equivalent area [31].

contact area can be approximated as a central rectangle and two half circles attached to its two ends that, overall, make up an $L \times 0.6 \mathrm{~L}$ figure as depicted in Figure 2(a). In this research, contact areas approximated to equivalent rectangle $0.8712 \mathrm{~L}$ in length and $0.6 \mathrm{~L}$ in width for simplicity (Figure 2(b)). Having internal tire pressure $(\rho)$ and wheel load $(P)$, pavement-tire contact area $(A)$ was obtained by Eq. (3). Thereafter, $L$ could be determined easily. 
Table 3. Properties of vehicle loads.

\begin{tabular}{lcccccc}
\hline \multicolumn{1}{c}{ Axle type } & $\begin{array}{c}\boldsymbol{P} \\
(\text { ton })\end{array}$ & $\begin{array}{c}\text { Load of a } \\
\text { single tire } \\
(\text { ton })\end{array}$ & $\begin{array}{c}\text { Length } \\
\text { of tire } \\
(\mathbf{m})\end{array}$ & $\begin{array}{c}\text { Width } \\
\text { of tire } \\
(\mathbf{m})\end{array}$ & $\begin{array}{c}\text { Contact } \\
\text { pressure } \\
(\mathbf{k P a})\end{array}$ & $\begin{array}{c}\text { Axle } \\
\text { width } \\
(\mathbf{m})\end{array}$ \\
\hline Single & 4 & 2 & 0.22 & 0.15 & 595 & 1.5 \\
Single & 8.2 & 4.1 & 0.45 & 0.31 & 288 & 1.7 \\
Single (double-tyre) & 13 & 3.25 & 0.32 & 0.22 & 453 & 1.8 \\
Tandem (double-tyre) & 22 & 2.75 & 0.36 & 0.25 & 300 & 1.9 \\
Tridem (single-tyre) & 26 & 4.33 & 0.466 & 0.31 & 294 & 2 \\
\hline
\end{tabular}

$$
A=\frac{P}{\rho} .
$$

Only vertical vehicle loads were considered in this research. Vehicles are generally classified into heavy, semiheavy, and light based on their weight and grouped into single, tandem, tridem, etc., depending on the number of axles. In design methods such as AASHTO and Asphalt Institute, different loads are equated with a specified equivalent load (8.2 ton) for convenience. In this research, in order to evaluate the influences of a wide range of vehicle types on the results, analyses were performed for different loadings consisting of $P=2$ tons (single), 4 tons (single), 8.2 tons (single), 13 tons (tandem), and 26 tons (tridem). Internal tire pressures were obtained from Continental Tires [32] and, accordingly, tire-pavement contact areas and load shapes were determined using Eq. (3). Properties of loads considered in the present study can be observed in Table 3 .

\section{Computer simulation of the problem}

Numerical simulation and analysis were performed employing finite element software of ABAQUS. Geocells were modeled with honeycomb structure made of $40 \times$ $40 \times 20 \mathrm{~cm}$ cubic cells by purely elastic shell elements. Pavement was considered to be made of surface, base, subbase, and subgrade layers, all of which behaved in elastic-perfectly plastic manner and obeyed MohrCoulomb failure criterion. Mechanical and geometrical properties of pavement layers and geocells assigned to the computer model can be seen in Table 1 . Soilgeocell interface was considered to be rough. Threedimensional view of the pavement model can be seen in Figure 3.

Pavement was reinforced once in the base course and once in subgrade layer and analyzed separately to evaluate the effects of base and subgrade reinforcement separately. Cross section of the pavement, reinforced in base and subbase layers, is shown in Figures 4 and 5, respectively. As shown by Figures 3 to 5 , width and length of the subgrade layer were $31 \mathrm{~m}$ and $30 \mathrm{~m}$, respectively. It should be noted that all dimensions were assigned with regard to the results

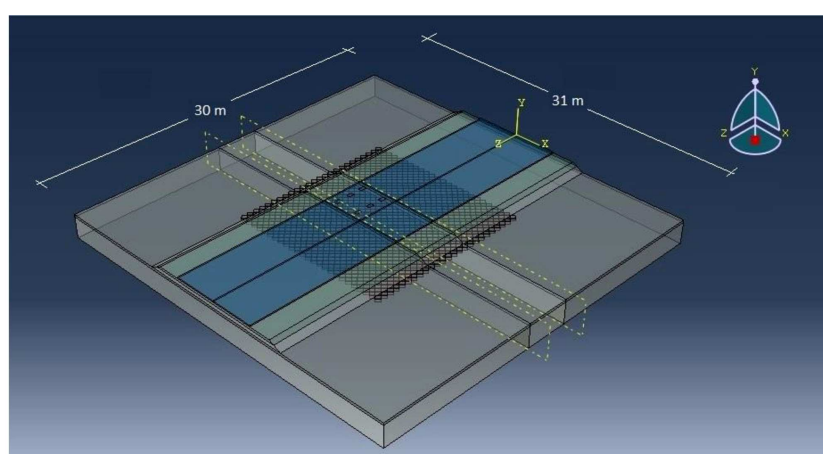

(a)

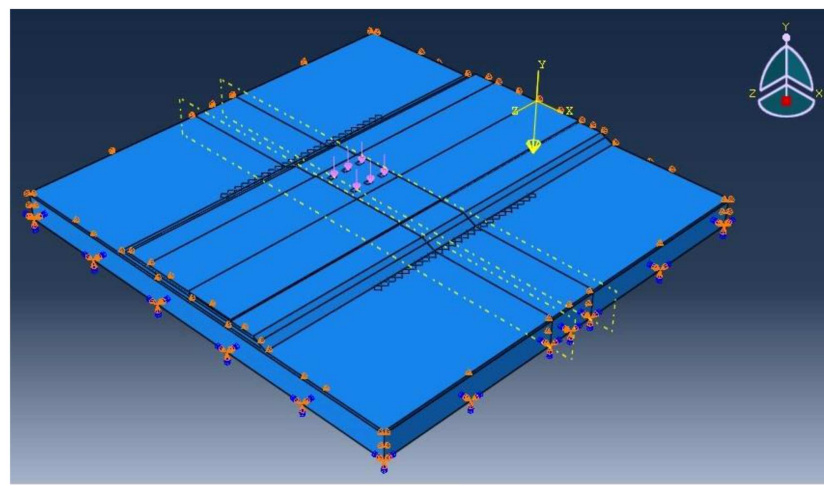

(b)

Figure 3. Three-dimensional view of geocell-reinforced model: (a) Reinforcement of subgrade and (b) loading and boundary conditions.

of the sensitivity analyses that indicated neglectable effect of larger dimensions on the shakedown results. Furthermore, sensitivity of mesh size to the shakedown result was investigated and the maximum size of an individual element was taken to be $2 \mathrm{~m}$.

As stated earlier, in total, five types of vehicle loads as characterized in Table 3 were considered for analysis. Simulated shapes of these loads in ABAQUS are shown in Figure 6. All the loads were applied at the extremity of the surface layer to simulate the most harmful effects.

\section{Verification}

In order to investigate the accuracy of the way soil-geocell composite was simulated in the present 


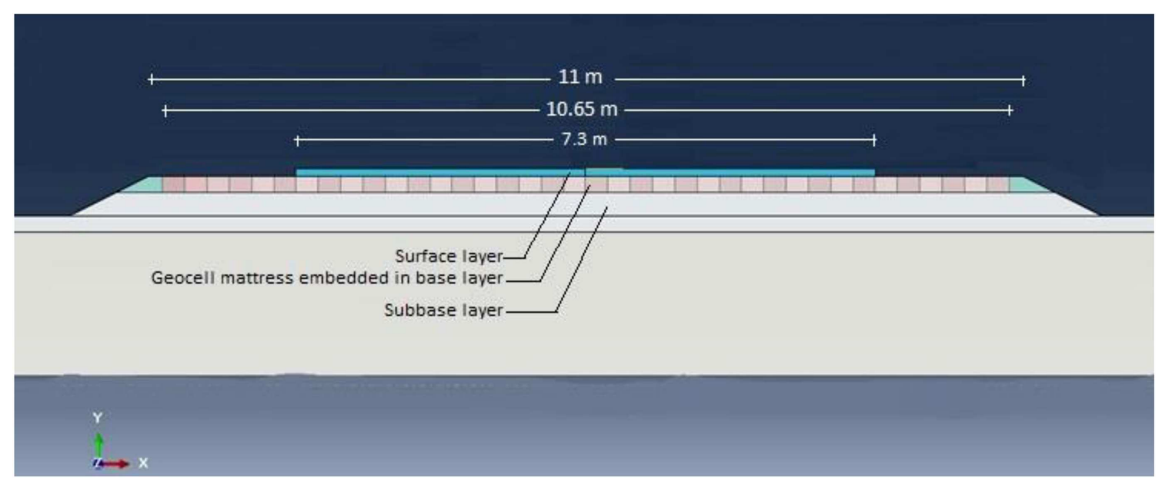

Figure 4. Cross section of the model reinforced in base layer.

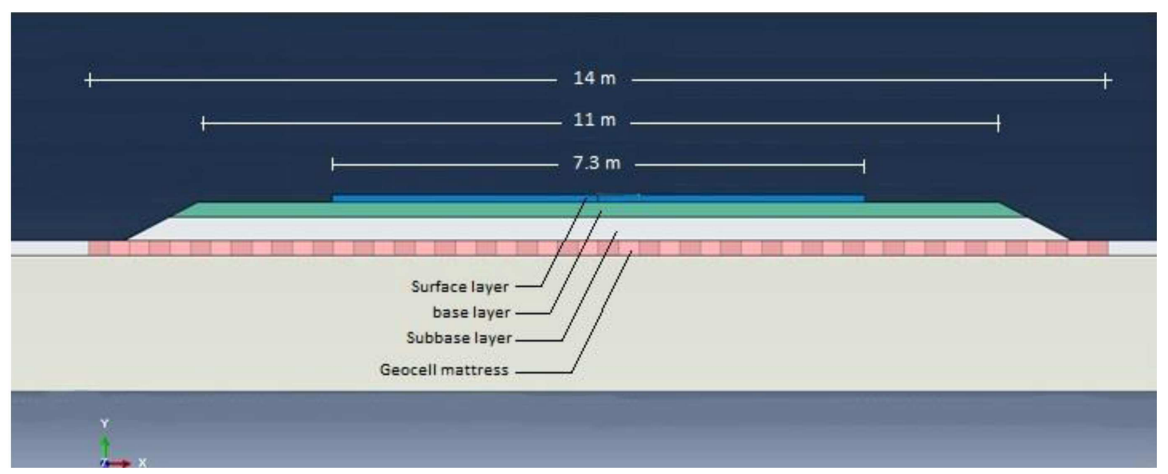

Figure 5. Cross section of the model reinforced in subgrade layer.

Table 4. Properties of soil and geocell used in Takur's laboratory model [33].

\begin{tabular}{lccccc}
\hline Material & $\begin{array}{c}\text { Cohesion } \\
(\mathbf{k P a})\end{array}$ & $\boldsymbol{\phi}^{\circ}$ & $\begin{array}{c}\boldsymbol{E} \\
(\mathbf{k P a})\end{array}$ & $\boldsymbol{\nu}$ & $\begin{array}{c}\boldsymbol{\gamma} \\
\left(\mathbf{k g} / \mathbf{m}^{\mathbf{3}}\right)\end{array}$ \\
\hline Soil & 30.68 & 12.9 & 196133 & 0.35 & 2080 \\
Geocell & - & - & 355000 & 0.35 & 2000 \\
\hline
\end{tabular}

study, results of Thakur's plate load tests on geocellreinforced soil were selected for verification [33]. Thakur embedded a geocell net having cell dimensions of $20 \times 23.5$ and $10 \mathrm{~cm}$ height into a $80 \times 80 \times 12 \mathrm{~cm} \mathrm{soil}$ that was enclosed by a rigid container and a gradual stress from zero to $595 \mathrm{kPa}$ was applied using a $15 \mathrm{~cm}$ diameter rigid circular plate (Figure 7(a)). Properties of soil and geocells that were used in Thakur's test are presented in Table 4.

The geometry, materials, and boundary conditions of the aforementioned laboratory test were simulated in ABAQUS and subjected to a loading identical to that tested in the laboratory. The computer model of Thakur's test is shown in Figure 7(b).

Figures 8 and 9 compare the results of loadvertical displacement of unreinforced and reinforced computer models with the corresponding laboratory tests, respectively. As Figures 8 and 9 show, there is a relatively good agreement between laboratory and computer models for both reinforced and unreinforced cases.

\section{Results}

Computer models of the unreinforced and reinforced pavements were subjected to the loads (as specified earlier) in a cyclic manner and then the load domain under which pavements showed shakedown behavior were determined through a trial and error process. Figures 10(a), 10(b), and 10(c) depict, respectively, the trial and error results related to unreinforced, reinforced base, and reinforced subgrade all subjected to cyclic 8.2-ton load as defined in Table 3.

These figures show the variation of maximum accumulated settlement of pavement surface under the applied loads, which are all a proportion of the initial 8.2-ton load by a load multiplier, $\alpha$, versus number of load cycles. As all three figures show, for most load multipliers $(\alpha)$ and for unreinforced, reinforced base, and reinforced subgrade, slope of the accumulated settlement versus number of load cycles tends to zero, which is identical to pavement elastic behavior; however, according to the adapted serviceability criteria, load multipliers causing surface accumulated settlement more than $1 \mathrm{~cm}$ are not acceptable. Besides, in addition to acceptable vertical displacement, the best (maximum) shakedown factor has to fulfill other 


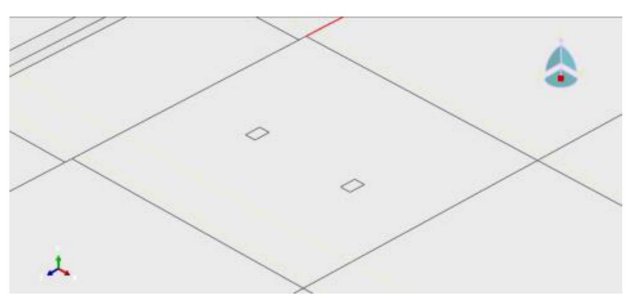

(a)

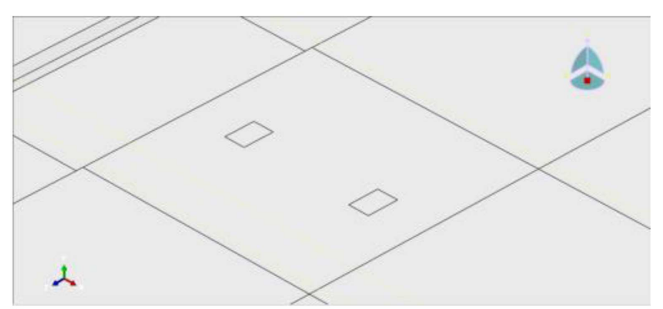

(b)

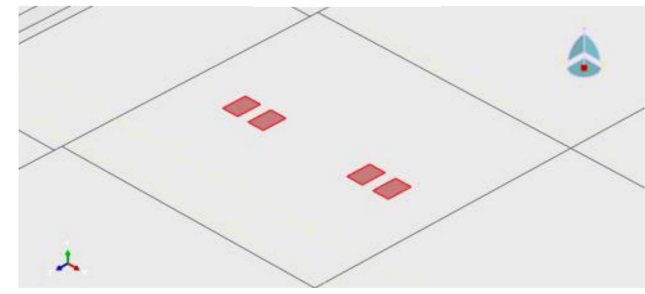

(c)

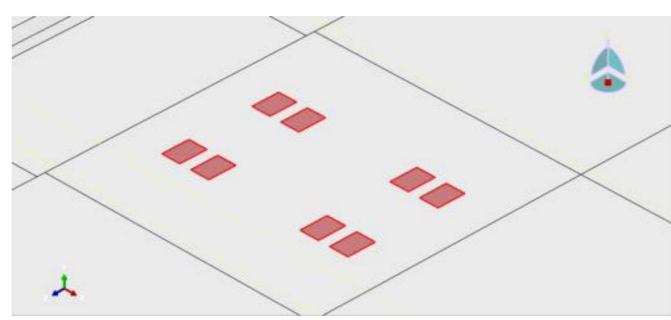

(d)

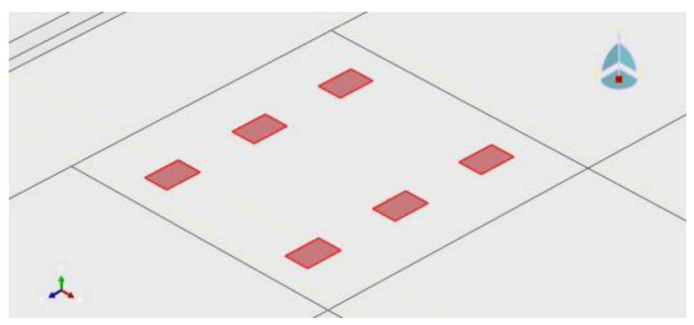

(e)

Figure 6. Shape of modeled loads: (a) Single axle, 4 tons, (b) single axle, 8.2 tons, (c) single axle, 13 tons, (d) tandem, 22 tons and (e) tridem, 26 tons.

serviceability criteria as described in the section on solution procedure. For example, $\alpha=7$ and $\alpha=7.5$ cannot be accepted as shakedown factors for subgradereinforced case, although they lead to vertical displacements less than $1 \mathrm{~cm}$ (Figure 10(c)). For the three situations shown in Figures 10(a) to 10(c), shakedown coefficients $(\lambda)$ are assessed 3.6 for unreinforced, 5 for
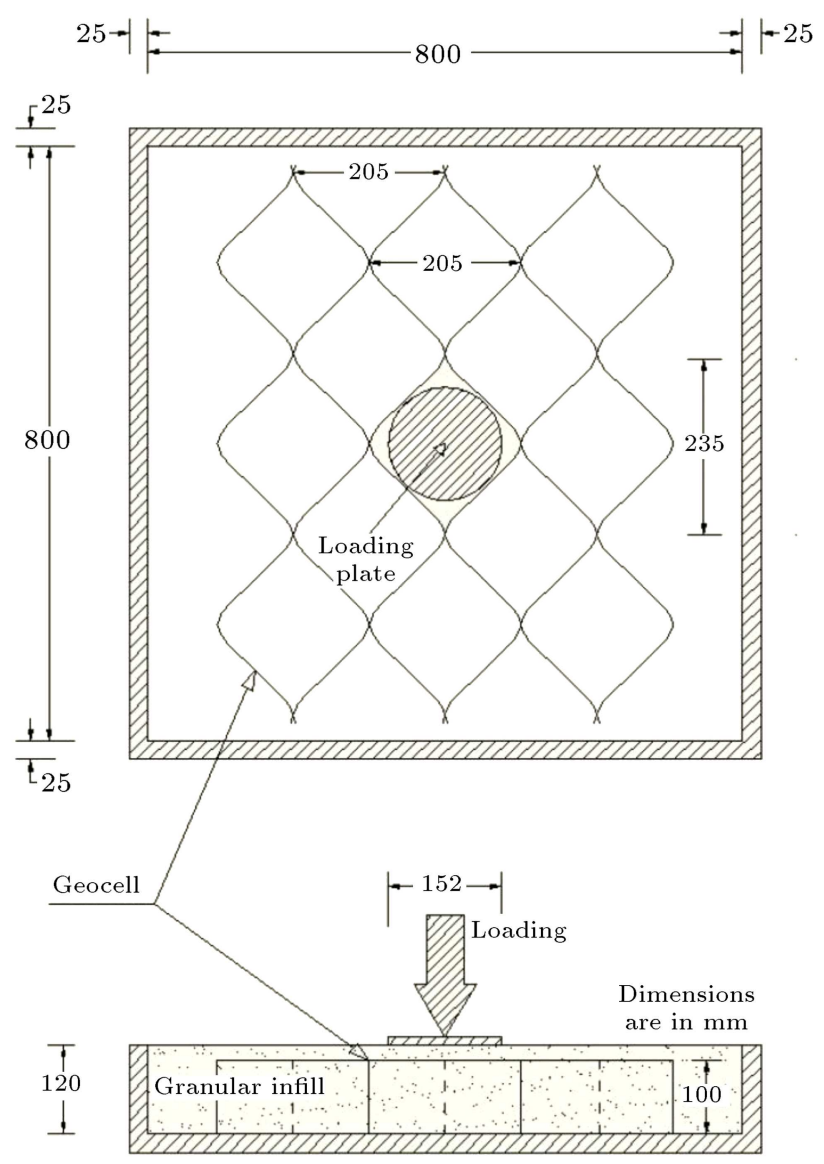

(a)

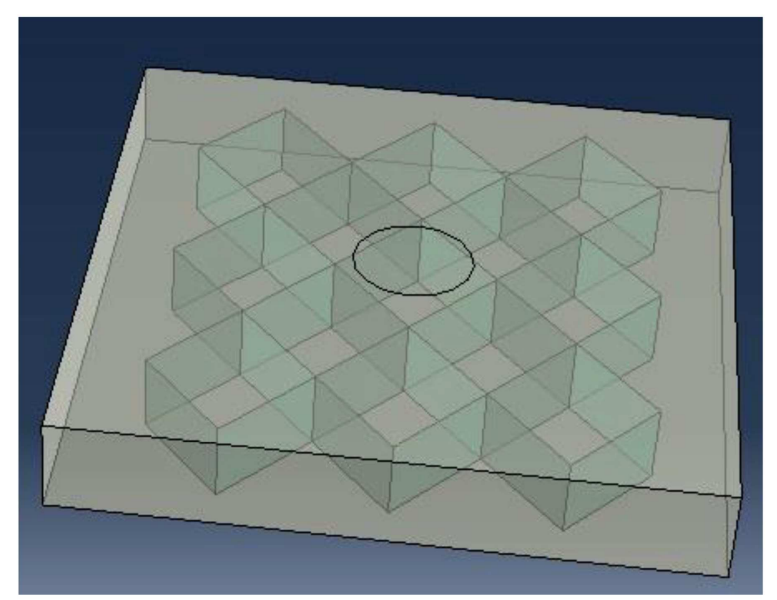

(b)

Figure 7. (a) Geometrical properties of Takur's experimental model [33]. (b) Three-dimensional view of Takur's model simulated in ABAQUS.

reinforced base, and 6 for reinforced subgrade. To determine the maximum possible value of $\alpha$, namely, shakedown factor or $\lambda$, all failure and serviceability criteria were taken in to account. Table 5 shows the results of the analysis to find shakedown factors associated with $P=22$ (tons) for all predefined cases of unreinforced, reinforced base, and reinforced subgrade. 


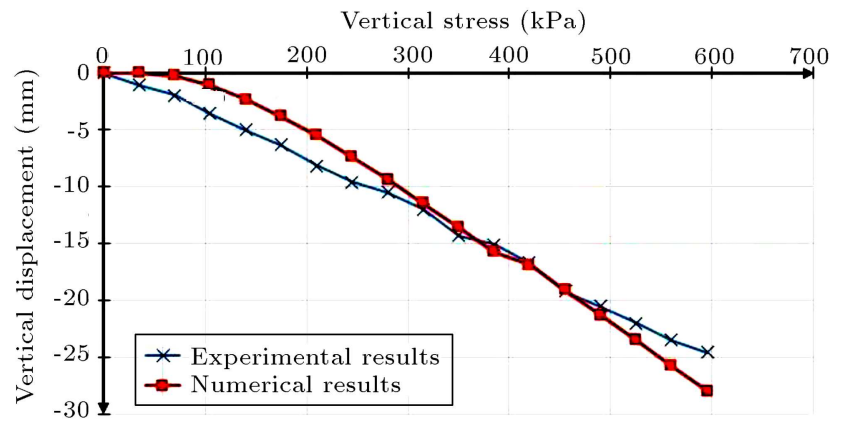

Figure 8. Comparison of load-displacement results of experimental model of Takur [33] and numerical simulation of the present study (unreinforced).

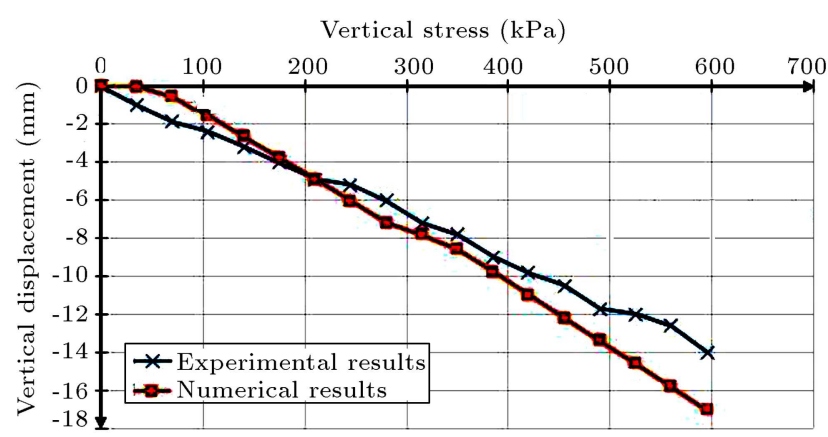

Figure 9. Comparison of load-displacement results of experimental model of Takur [33] and numerical simulation of the present study (reinforced).

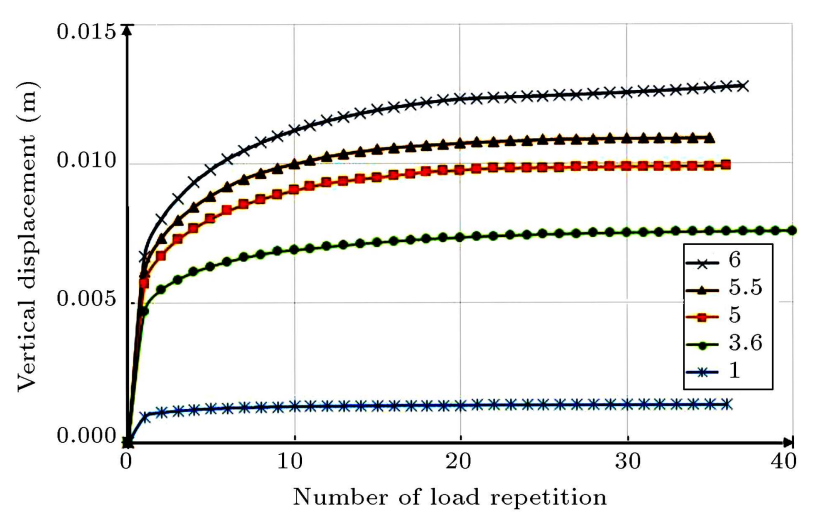

Figure 10(a). Try and error efforts to obtain the best (maximum) shakedown factor for unreinforced pavement under $P=8.2$ tons.

As Table 5 indicates, tensile strain beneath asphalt layer and compressive strain on top of the subgrade layer are smaller than the corresponding critical values.

Figure 11 represents the variation of $\lambda$ for different

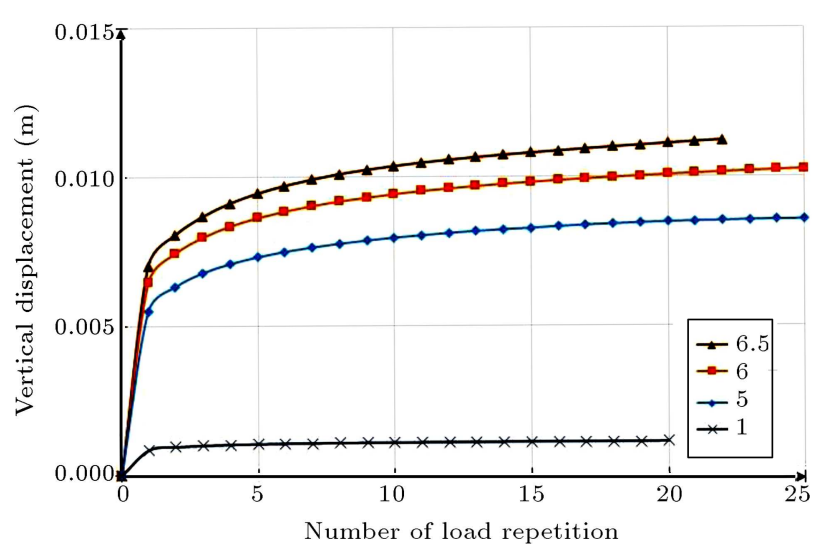

Figure 10(b). Try and error efforts to obtain the best (maximum) shakedown factor for base-reinforced pavement under $P=8.2$ tons.

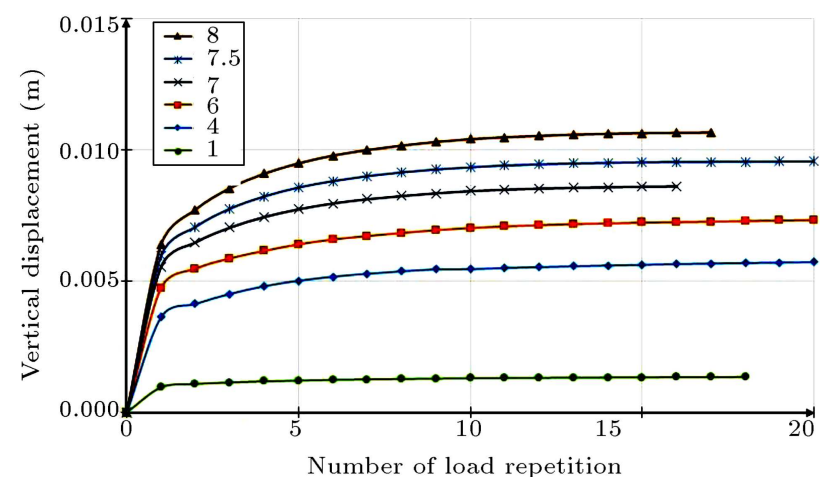

Figure 10(c). Try and error efforts to obtain the best (maximum) shakedown factor for subgrade-reinforced pavement under $P=8.2$ tons.

loads. As indicated in Figure 11, shakedown factor for the pavement reinforced in subgrade is always larger than that for the pavement reinforced in the base layer, and unreinforced pavement always leads to the smallest value of $\lambda$. This clearly suggests the positive effects of geocell reinforcement on the improvement of shakedown behavior of pavements. Reinforcement of subgrade by geocell has led to a 33 to 150 percent growth in $\lambda$ value for unreinforced pavements. Such an increase is in the range of $5 \%$ to $67 \%$ for the pavement reinforced in the base layer. There are at least two reasons behind reinforced subgrade being more influential than reinforced base in terms of shakedown factor. Firstly, width of the geocells embedded in base layer is smaller than that of the geocells placed in the subgrade layer due to construction limitation and, hence, less load transformation is possible in such a situation.

Table 5. Results of shakedown analysis for $P=22$ (tons).

\begin{tabular}{lcccccc}
\hline \multicolumn{1}{c}{ Type } & $\varepsilon_{\boldsymbol{c}}$ & $\boldsymbol{\varepsilon}_{\boldsymbol{c}}^{f}$ & $\boldsymbol{\varepsilon}_{\boldsymbol{t}}$ & $\boldsymbol{\varepsilon}_{\boldsymbol{t}}^{f}$ & $\boldsymbol{N}_{\boldsymbol{f}}$ & $\boldsymbol{\lambda}$ \\
\hline Unreinforced & 0.0057 & 0.010479 & 0.0000065 & 0.004599 & 51 & 1 \\
Reinforced base & 0.009165 & 0.011067 & 0.0002515 & 0.004915 & 41 & 1.3 \\
Reinforced subgrade & 0.011436 & 0.01293 & 0.0002871 & 0.005938 & 23 & 1.7 \\
\hline
\end{tabular}




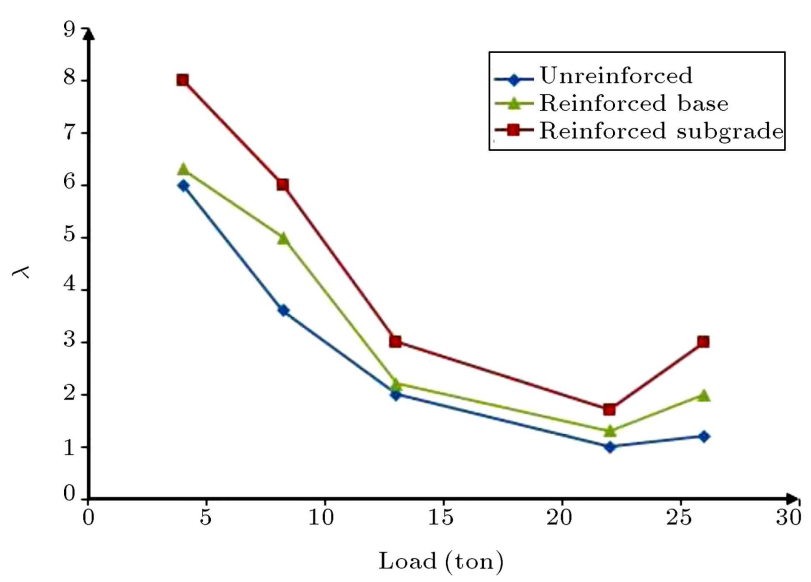

Figure 11. Shakedown coefficient $(\lambda)$ versus vehicle loads for different types of geocell reinforcement.

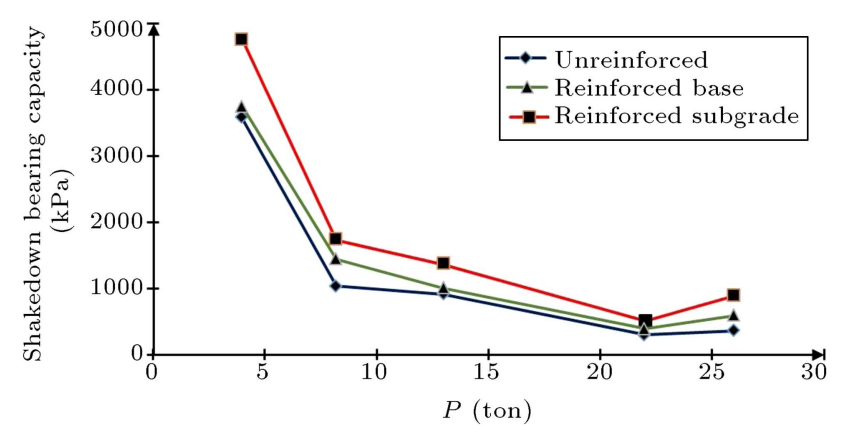

Figure 12. Shakedown bearing capacity versus vehicle loads for different types of geocell reinforcement.

Secondly, unreinforced subgrade soil is much weaker in strength than unreinforced base material and strengthening such a weak layer is naturally more effective than strengthening a strong layer. Furthermore, as depicted in Figure 11, regardless of pavement type (reinforced or unreinforced), shakedown factor is maximum for $P=4$ tons and minimum for $P=22$ tons. This finding suggests that in addition to the initial load intensity, load shape can influence the shakedown results. As Table 3 and Figure 6 show, although a 22-ton vehicle causes $300 \mathrm{kPa}$ stress beneath each tire, which is not the maximum value compared to other given vehicles, its effect has increased due to having double tires beside each other. This is true for $P=13$ tons as well. The minimum value of $\lambda$ belongs to unreinforced pavements under $P=22$ tons and is equal to one. It means that for the cases under consideration, all given loads are safe in terms of shakedown failure criterion.

By multiplication of shakedown factor by initial stress, shakedown bearing capacity is obtained. Shakedown bearing capacity versus vehicle loads diagram has been presented in Figure 12. It is implied in Figure 12 that the same trend for $\lambda-P$ diagram holds here. A new point is that maximum allowable stress for each kind of tire regarding all types of vehicle that may possibly move on a specified pavement can

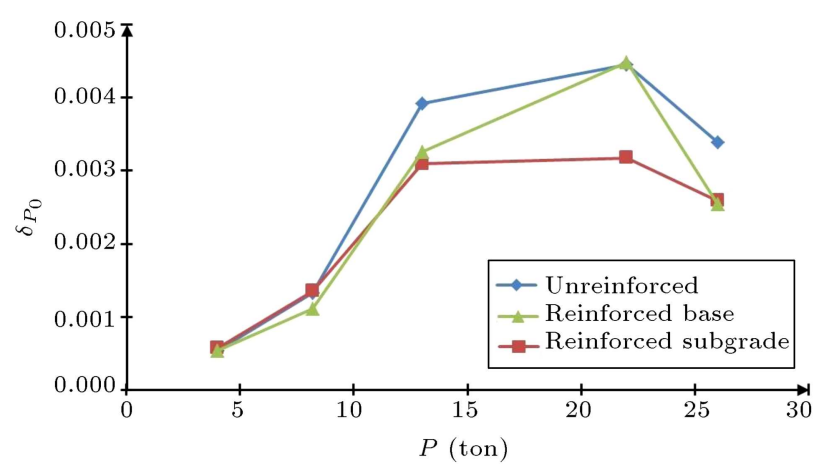

Figure 13. Accumulated surface settlement under repeated unfactored loads.

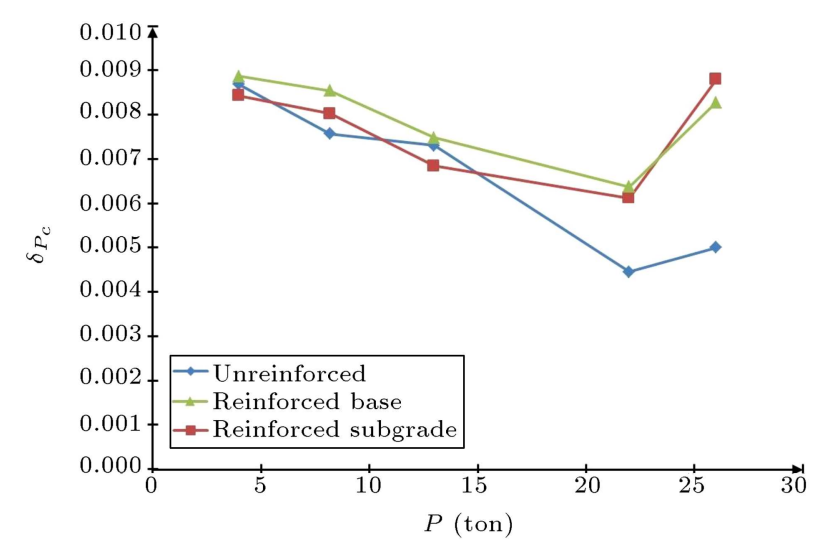

Figure 14. Accumulated surface settlement under repeated factored loads.

be determined from such a diagram. For the present pavement, maximum allowable stresses for each tire of a 22 -ton vehicle are $300 \mathrm{kPa}, 390 \mathrm{kPa}$, and $510 \mathrm{kPa}$ for unreinforced, reinforced base, and reinforced subgrade, respectively.

Accumulated plastic settlement of the pavements on the surface layer due to unfactored loads $\left(\delta_{P_{0}}\right)$ and factored loads $\left(\delta_{P_{c}}\right)$ can be observed in Figures 13 and 14 , respectively.

As shown in Figure $13, \delta_{P_{0}}$ first increases with increase in $P$ and then falls as $P$ grows so that it reaches a peak at $P=22$ tons. Although the variations of $\delta_{P_{0}}$ with $P$ show the same trend for unreinforced and reinforced cases, these variations are not obvious for three different cases of unreinforced, reinforced base, and reinforced subgrade relative to each other. However, pavement reinforced in subgrade mostly shows the lowest $\delta_{P_{0}}$ as Figure 13 indicates. In its best performance, reinforced subgrade has caused $28 \%$ percent decrease in $\delta_{P_{0}}$ at $P=22$ tons compared to unreinforced case. It should be noted that $\delta_{P_{0}}$ is only one of the three serviceability criteria considered to determine whether the unfactored loads cause shakedown of pavement or not. As Figure 14 shows, variation of $\delta_{P_{c}}$ with $P$ is quite the reverse of $\delta_{P_{0}}$, i.e., first a drop and then a growth in $\delta_{P_{c}}$ are observed as $P$ increases. 
Just like $\lambda$ and $\delta_{P_{0}}$, the most extreme value of $\delta_{P_{c}}$, i.e. the minimum value, is observed in $P=22$ tons. $\delta_{P_{c}}$ is mostly lower for pavement reinforced in subgrade compared to unreinforced and reinforced subgrade cases and shows $40 \%$ decrease at $P=26$ tons compared to unreinforced state. Although accumulated settlements under traffic loads discussed above are all in acceptable range, their values compared to each other can be used as an index to compare serviceability of different types of pavements or reinforcements.

\section{Conclusions}

The present paper is devoted to numerical evaluation of the effects of geocell reinforcement on the behavior of a flexible pavement under repeated loads of traffic. Shakedown phenomenon was considered as safety criterion and load domain was bounded in this regard so that safe loads were a multiplication of shakedown load by the initial loads. Both failure and serviceability criteria were included in the determination of shakedown coefficient $(\lambda)$. Three cases, namely, unreinforced, base reinforced, and subgrade reinforced pavements, were considered and analyzed to see the influence of geocell reinforcement and place of geocell on safety of the pavements. Finite element software of ABAQUS was used for simulation and analysis of the reinforced and unreinforced pavements. Five different loads, namely, three single axle loads of 4 tons, 8.2 tons, and 13 tons, one tandem axle load of 22 tons, and a tridem axle load of 26 tons, were applied on the pavements in a repetive manner. Analysis resulted in the following findings:

1. Reinforcement of pavement by geocell always leads to increase in coefficient of shakedown, regardless of the place of embedded geocell (inside the base or subgrade layers) or type of load. However, reinforcement of subgrade by geocell is more influential than base reinforcement to increase the $\lambda$ value;

2. Shakedown coefficients are different depending on the load intensity and contact area, so that for the cases investigated, minimum value of $\lambda$ is obtained for $P=22$ ton;

3. Shakedown bearing capacity is observed to follow the same trend as shakedown coefficient. It is discussed whether shakedown analysis can be used to assess critical bearing capacity of a specified pavement in terms of shakedown failure criteria if characteristics of all loads that can possibly be applied on the pavement are known;

4. Examining the maximum accumulated vertical displacement prior to shakedown state of surface layer for unfactored $(\lambda=1)$ loads $\left(\delta_{P_{0}}\right)$ shows that $\delta_{P_{0}}$ first increases with $P$, peaks at $P=22$ tons, and then drops at larger values of $P$. Reinforced subgrade results mostly in the lowest amounts of $\delta_{P_{0}}$

5. Variation of maximum accumulated vertical displacement prior to shakedown state of surface layer $\left(\delta_{P_{c}}\right)$ for factored $(\lambda \# 1)$ loads with $P$ indicates that the trend is the reverse of $\delta_{P_{0}}$ and here, minimum, rather than maximum, $\delta_{P_{c}}$ is observed at $P=$ 22 tons. Unlike $\delta_{P_{0}}$, base reinforcement mostly leads to the lowest values of $\delta_{P_{c}}$.

As noted earlier, employing numerical loaddisplacement methods to find shakedown limit of pavements has been avoided so far mainly due to its complex and time-taking nature. However, such methods are the most reliable thanks to their capability of involving all shakedown criteria. Taking into account the effective factors such as rate of traffic and modeling, the tire loads as much as possible similar to the real traffic loads, e.g. moving dynamic loads, may give rise to more genuine results. Of course, such an achievement requires great time and computing facilities, especially in case of reinforced pavements.

\section{References}

1. Jupsi, S. "Experimental validation of the shakedown concept for pavement analysis and design", Ph.D. Thesis, University of Nottingham (2007).

2. Ravindra, P.S. and Small, J.C. "Shakedown analysis of road pavements", The 12th International Conference of International Association for Computer Methods and Advances in Geomechanics Goa, India, pp. 44324438 (2008).

3. Ravindra, P.S. "Shakedown analysis of road pavements - an experimental point of view", Ph.D. Thesis, University of Sydney (2008).

4. Melan, E. "The state of tension of a Mises-Hencky's continuum under load" [Der Spanning Zustand Eines Mises Henckyschen Kontinuums Bei Verändlichen Belastung], 147, pp. 73-87 (1938).

5. Koiter, W.T. "General theorems for elastic-plastic solids", In Progress in Solid Mechanics, J.N. Sneden, and R. Hill, Eds., 1, North Holland, Amsterdam, pp. 162-221 (1960).

6. Sharp, R.W. and Booker, J.R. "Shakedown of pavement under moving surface loas", Journal of Transportation Engineering, 110, pp. 1-14 (1984).

7. Raad, L., Weichert, D. and Najm, W. "Stability of multilayer systems under repeated loads", Transportation Research Record, 1207, pp. 181-186 (1988).

8. Raad, L., Weichert, D., and Haidar, A. "Analysis of full-depth asphalt concrete pavements using shake- 
down theory", Transportation Research Record, 1227, pp. 53-65 (1989).

9. Collins, I.F. and Cliffe, P.F. "Shakedown in frictional materials undermoving surface loads", International Journal for Numerical and Analytical Methods in Geomechanics, 11, pp. 409-420 (1987).

10. Collins, I.F., Wang, A.P., and Saunders, L.R. "Shakedown in layered pavements under moving surface loads", International Journal for Numerical and Analytical Methods in Geomechanics, 17, pp. 165-174 (1993).

11. Collins, I.F., Wang, A.P., and Saunders, L.R. "Shakedown theory and the design of unbound pavements", Road and Transport Research, 2(4), pp. 29-38 (1993).

12. Collins, I.F. and Boulbibane, M. "Geomechanical analysis of unbound pavements based on shakedown theory", Journal of Geotechnical and Geoenvironmental Engineering, ASCE, 126(1), pp. 50-59 (2000).

13. Collins, I.F. and Boulbibane, M. "Shakedown under moving loads with applications to pavement design and wear", Proceedings of the John Booker Memorial Symposium, D.W. Smith and J.P. Carter, Eds., University of Sydney, NSW, Australia (2000).

14. Yu, H.S. and Hossain, M.Z. "Lower bound shakedown analysis of layered pavements using discontinuous stress fields", Computer Methods in Applied Mechanics and Engineering, 167, pp. 209-222 (1998).

15. Shiau, S.H. "Numerical methods for shakedown analysis of pavements under moving surface loads", Ph.D. Thesis, The University of Newcastle (2001).

16. Webster, S.L. and Watkins, J.E. "Investigation of construction techniques for tactical bridge approach roads across soft ground", Technical Rep. No. S-77-1, U.S. Army Engineer Water ways Experiment Station, Vicksburg, Miss (1977).

17. Huang, X. and Han, J. "Geocell-reinforced granular fill under static and cyclic loading: a synthesis of analysis", Geotechnical Engineering Journal of the SEAGS \& AGSSEA, 44(4), pp. 17-23 (2013).

18. Bathurst, R.J. and Karpurapu, R. "Large scale triaxial compression testing of geocell reinforced granular soils", Geotechnical Testing Journal, 16, pp. 296-303 (1993).

19. Rajagopal, K., Krishnaswamy, G., and Madhavi Latha, G. "Behaviour of sand confined with single and multiple Geocells", Journal of Geotextile and Geomembranes, 17, pp. 171-184 (1999).

20. Latha, G.M., Nair, A.M., and Hemalatha, M.S. "Performance of geosynthetics in unpaved roads", International Journal of Geotechnical Engineering, 4(2), pp. 151-164 (2010).
21. Mhaiskar, S.Y. and Mandal, J.N. "Three dimensional geocell structure: performance under repetive loads", 5th International conference on Geotextiles, Geomembranes, and Related Products, Singapore, pp. 155-158 (1994).

22. Madhavi Latha, G. and Somwanshi, A. "Effect of reinforcement form on the bearing capacity of square footings on sand", Geotextiles and Geomembranes, 27(6), pp. 409-422 (2009).

23. Han, J., Yang, X.M., Leshchinsky, D., Parsons, R.L., and Rosen, A. "Numerical analysis for mechanisms of a geocell-reinforced base under a vertical load", Proceedings of the 4th Asian Regional Conference on Geosynthetics, June 17-20, Shanghai, China, pp. 741746 (2008).

24. Madhavi Latha, G., Dash, S.K., and Rajagopal, K. "Numerical simulation of the behavior of geocell reinforced sand in foundations", International Journal of Geomechanics, 9(4), pp. 143-152 (2009).

25. Chazallon, C., Koval, G., Hornych, P., Allou, F., and Mouhoubi, S. "Modelling of rutting of two flexible pavements with the shakedown theory and the finite element method", Computers and Geotechnics, 36, pp. 798-809 (2009).

26. Yang, X., Han, J., Leshchinsky, D., and Parsond, R.L. "A three-dimensional mechanistic-empirical model for geocell reinforced unpaved roads", Acta. Geotechnica., 8(2), pp. 201-213 (2013).

27. Leshchinsky, B. and Ling, H.I. "Numerical modeling of behavior of railway ballasted structure with geocell confinement", Geotextiles \& Geomembranes, 36(1), pp. 33-43 (2013).

28. Leshchinsky, B. and Ling, H.I. "Effects of geocell confinement on strength and deformation behavior of gravel", J. Geotech. Geoenviron. Eng., 139, pp. 340352 (2013).

29. The Asphalt Institute, MS-2, Mix Design Methods for Asphalt Concrete and Other Hot Mix Types (1984).

30. AASHTO, Guide for Design of New and Rehabilitated Pavement Structures, American Association of State Highway and Transportation Officials, America (2002).

31. Huang, Y.H., Pavement Analysis and Design, Pearson Education Inc, Second Edition (2004).

32. http://www.continental-tires.com.

33. Thakur, J.K. "Experimental study on geocell-reinforced recycled asphalt pavement (RAP) bases under static and cyclic loading", MSc Thesis, University of Kansas (2010).

\section{Biographies}

Mohammad Reza Arvin received his BSc degree in Civil Engineering from Technical University of Shahrood in 1998. After being practically active in construction industry for three years, he was accepted for MSc degree in the field of Soil Mechanics and 
Foundation at Shiraz University and graduated as the top student in 2006. Immediately after that, he started the PhD program in Geotechnical Earthquake Engineering at International Institute of Earthquake Engineering and Seismology (IIEES), during which he was working on the application of the lower bound dynamic shakedown theory on the seismic stability of slopes. His main research interests are application of limit state methods in geotechnical problems, geotechnical earthquake engineering, and optimization.

Ehsan Rezaei received the MSc degree in Soil Mechanics and Foundation from Fasa University. He worked for about 2 years on the evaluation of the shakedown behavior of roads under traffic loads under the supervision of Dr. Arvin. To do so, he managed to acquire proper knowledge of the finite element based software of ABAQUS in order to simulate the complex model of geocell-soil composite.

Mostafa Bahmani Shoorijeh received the BSc degree in Civil Engineering from Shiraz University and MSc degree in Geotechnical Engineering form Isfahan University of Technology. He is a Researcher who is interested in different areas of numerical modelling, including nonlinear finite element methods, discrete element method, and coupling of these methods with computational fluid dynamics. He has sufficient experience in numerical simulation of different types of geotechnical structures. His research is recently focused on experimental and numerical modeling of scour and erosion. 